\title{
Difference in the Concentration of Macro Elements between Organically and Conventionally Grown Vegetables
}

\author{
Martyna Głodowska1, Józef Krawczyk² \\ ${ }^{1}$ Department of Ecology, Biogeochemistry and Environmental Protection, Wroclaw University, Wroclaw, Poland \\ ${ }^{2}$ Centre for Modern Biology Teaching Strategies, Wroclaw University, Wroclaw, Poland \\ Email: glodowska.m@gmail. com
}

How to cite this paper: Glodowska, M. and Krawczyk, J. (2019) Difference in the Concentration of Macro Elements between Organically and Conventionally Grown Vegetables. Agricultural Sciences, 10, 267-277. https://doi.org/10.4236/as.2019.103023

Received: January 15, 2019

Accepted: March 10, 2019

Published: March 13, 2019

Copyright (อ 2019 by author(s) and Scientific Research Publishing Inc. This work is licensed under the Creative Commons Attribution International License (CC BY 4.0).

http://creativecommons.org/licenses/by/4.0/

\section{(c) (i) Open Access}

\begin{abstract}
Although the quality of organic crops has been intensively studied for over three decades, there is still a lack of conclusive data that can prove the superiority of organic crops over conventional ones. There is no doubt that the organic food is safer due to the lack of pesticide residues; however, it is still not entirely sure whether vegetables and fruits produced in this way are better in the context of nutritional values. The study of commonly used vegetables in the European diet was performed to evaluate the difference in concentration of macro nutrients such as $\mathrm{Ca}, \mathrm{Mg}, \mathrm{Na}, \mathrm{N}, \mathrm{K}$ and $\mathrm{P}$ between organic and conventional crops. Additionally, the soil analysis was performed on the material from two growing systems. The results showed that organically cultivated vegetables had generally a higher level of macro nutrients. Also, soil samples showed higher content of these elements in the organically treated soil. From all vegetables, the highest concentrations of macro elements were found in parsley leaves and celery roots.
\end{abstract}

\section{Keywords}

Conventional Farming, Macro Elements, Organic Farming, Soil, Vegetables

\section{Introduction}

Most consumers in developed countries are convinced about the higher quality of organically grown fruits and vegetables. It is generally believed that organic food is healthier than the one produced in a conventional way. This perception emerged from the general opinion that organic food was more nutritious, had more vitamins and did not contain pesticide and fertilizer residues. It is often true that there are many advantages of organic food which is clearly presented in 
the review article based on a meta-analysis performed by Barański and coworkers [1]. Many studies demonstrated that organic crops do not contain pesticide residues or have an insignificant amount of them [2] [3]. It is also shown that fruits and vegetables produced organically usually have more vitamin $\mathrm{C}$ and $\beta$-carotene [4] [5]. Furthermore, several studies report that organic food has a better flavor and higher organoleptic qualities [6] [7]. However, there is still a lack of conclusive data that can confirm the superiority of organic crops over conventional ones in the context of nutritional values. Are organic vegetables really more nutritious and do they have a higher level of macro and micro elements? Some authors reported that vegetables grown in an organic way did not differ in the concentration of nutrients or the difference was insignificant [5] [6]. Moreover, some authors suggest that the organic crops might be the source of the microbiological contamination due to the use of organic fertilizers which are commonly applied in this farming system [8].

Although the subject of organic vs. conventional farming has been present in the public debates for a long time, it is still raising many controversies, particularly among consumers who demand the right to know the quality of food products. Many studies have been conducted in order to provide reliable data. However, there is still a lack of consistent and unambiguous studies that can confirm the superiority of one growing system over another. Taking into account that the final chemical composition of the crop is strongly influenced by external factors such as physicochemical properties of the soil, climate conditions, plant varieties, and type of applied fertilizers, it makes it extremely difficult to compare the data from different studies. In order to clearly demonstrate the differences in the quality of agricultural products of both types of farming systems detailed, ideally, long-term and very reliable research is required.

The main goal of this study is to evaluate the differences in the concentration of major macro nutrients such as $\mathrm{Ca}, \mathrm{Mg}, \mathrm{N}, \mathrm{Na}, \mathrm{K}$, and $\mathrm{P}$ in the commonly consumed vegetables grown in organic and conventional ways. Additionally, the concentration of macro elements was assessed in the soils of both growing systems. Furthermore, the study tried to indicate which vegetables accumulated the most nutrients.

\section{Materials and Methods}

For the study, vegetables commonly used in the Eastern and Central European diet were selected. The following were assessed: root of parsley (Petroselinum crispum), beet (Beta vulgaris L.), celery (Apiumgraveolens L.) and carrot (Daucus carota L.), bulb of onion (Allium cepa L.) and leek (Allium porrum L.), potato tuber (Solanum tuberosum L.) and leaves of parsley. The vegetables were harvested from two private farms in mid-autumn of 2010; conventional

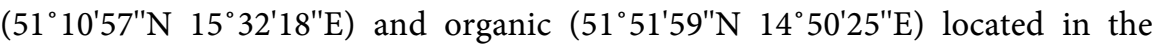
western part of Poland. In the conventional farm, compound fertilizers (NPK) were regularly applied during the growing season, as well as nitrogen, phospho- 
rus and some organic fertilizers, whereas, in the organic farm only compost and green manure were applied together with lime to increase the $\mathrm{pH}$. Soil samples from both farms were collected at the same time as vegetables at $10-15 \mathrm{~cm}$ depth which corresponds to the plant root zone from where nutrients are usually absorbed. The collected plants and soil samples were transported to the laboratory in paper bags. Fresh soil samples were used for the determination of $\mathrm{pH}$. The plants were washed with distilled water, cut into small pieces and dried at $80^{\circ} \mathrm{C}$ for $24 \mathrm{~h}$. Completely dry plants were ground in the laboratory grinder (IKA M20). Soil samples were air-dried at room temperature $\left(21^{\circ} \mathrm{C}\right)$ and organic matter was removed. Afterwards, soil samples were passed through a $2 \mathrm{~mm}$ sieve and homogenized using a mortar and pestle. Once homogenized, plant material (500 mg of dry weight) was digested with $3 \mathrm{ml}$ of concentrated nitric acid (68\%, ultra pure) and $2 \mathrm{ml}$ of hydrogen peroxide (35\%, pro-analysis) until the evolution of nitrous oxide gas stopped and the digest became clear. Afterwards, samples were diluted to $50 \mathrm{ml}$, the plant digests were analysed for $\mathrm{Mg}$ using FAAS with an AVANTA PM Atomic Absorption Spectrophotometer from the GBC Scientific Equipment. The analysis was carried out in triplicate and the Mg was measured against standards (Atomic Absorption Standard Solution from Sigma Chemical Co.). The concentration of $\mathrm{P}$ in the plant tissues was evaluated using a colorimetric method with ammonium molybdate [9]. The content of $\mathrm{Na}, \mathrm{Ca}$, and $\mathrm{K}$ were assessed using a PFP7 flame photometer [10]. The total nitrogen concentration in plants and soils was determined by the Kjeldahl method (ISO 11261:1995) using a VAPODEST 40 automatic steam distillation apparatus (GERHARDT). The content of the exchangeable cations $\left(\mathrm{Ca}^{2+}, \mathrm{Na}^{+}, \mathrm{Mg}^{+}\right.$, and $\mathrm{K}^{+}$) in the soil was determined by Pallman methods in a $1 \mathrm{M}$ ammonium chloride solution. The concentration of $\mathrm{Ca}, \mathrm{Na}$ and $\mathrm{K}$ was assessed using a flame photometer and the concentration of $\mathrm{Mg}$ was assessed by Atomic Absorption Spectrophotometer. The soil available $\mathrm{P}$ was evaluated with ammonium molybdate in an extract prepared with $0.03 \mathrm{M}$ acetic acid by a colorimetric method [9]. The results were calculated on a dry weight basis.

The obtained results were analyzed using statistical methods. The student's t-test was applied to evaluate the significance of differences in the concentration of chemical elements among the vegetables of the two growing systems. The statistical analysis was performed using the STATISTICA 9.1 software (Statsoft 2010).

\section{Results}

The results of macro elements' concentration in the vegetables are presented in Table 1. Statistical analysis revealed significant differences in the average concentration of macro elements between the vegetables grown in the organic and conventional systems.

Particularly high concentration of $\mathrm{Ca}$ was recorded in parsley leaves, which was 8490 and $13921 \mathrm{mg} \cdot \mathrm{kg}^{-1}$ for organic and conventional one, respectively. Generally, organic vegetables revealed an increased level of this element, and the 
Table 1. Mean and standard deviation (SD) of macro elements $\left(\mathrm{mg} \cdot \mathrm{kg}^{-1}\right)$ in the organically and conventionally grown vegetables.

\begin{tabular}{|c|c|c|c|c|c|c|}
\hline & $\mathrm{Ca}$ & $\mathrm{Mg}$ & $\mathbf{N}$ & $\mathrm{Na}$ & $\mathrm{K}$ & $\mathbf{P}$ \\
\hline \multicolumn{7}{|l|}{ Parsley (root) } \\
\hline Organic & 1998 & 2038 & 15,260 & 476 & 22,062 & 3179 \\
\hline $\mathrm{SD}$ & 59.0 & 42.1 & 2590 & 18.4 & 1014 & 0.000 \\
\hline Conventional & 1879 & 1908 & 11,270 & 350 & 20,728 & 3050 \\
\hline SD & 29.4 & 75.1 & 1120 & 24.6 & 611 & 38.7 \\
\hline $\mathrm{p}$ & 0.035 & 0.059 & 0.071 & 0.002 & 0.123 & 0.004 \\
\hline \multicolumn{7}{|l|}{ Beet } \\
\hline Organic & 1845 & 1897 & 12,740 & 1133 & 17,731 & 2087 \\
\hline $\mathrm{SD}$ & 77.6 & 66.9 & 490 & 34.3 & 778 & 19.3 \\
\hline Conventional & 1930 & 1449 & 9660 & 566 & 21,436 & 2604 \\
\hline $\mathrm{SD}$ & 29.4 & 16.0 & 350 & 29.1 & 234 & 510 \\
\hline $\mathrm{p}$ & 0.152 & 0.000 & 0.001 & 0.000 & 0.001 & 0.155 \\
\hline \multicolumn{7}{|l|}{ Parsley (leaves) } \\
\hline Organic & 8490 & 2886 & 36,680 & 322 & 69,066 & 4323 \\
\hline $\mathrm{SD}$ & 757 & 443 & 7910 & 50.6 & 2975 & 84.0 \\
\hline Conventional & 13921 & 2568 & 25,270 & 403 & 60,811 & 3418 \\
\hline $\mathrm{SD}$ & 1344 & 0.000 & 700 & 121 & 7991 & 264 \\
\hline $\mathrm{p}$ & 0.004 & 0.282 & 0.068 & 0.345 & 0.169 & 0.005 \\
\hline \multicolumn{7}{|l|}{ Leek } \\
\hline Organic & 2444 & 1585 & 11,900 & 223 & 22,847 & 2791 \\
\hline $\mathrm{SD}$ & 79.1 & 5.68 & 350 & 24.9 & 954 & 25.8 \\
\hline Conventional & 2496 & 1404 & 14210 & 235 & 22,949 & 2630 \\
\hline $\mathrm{SD}$ & 29.9 & 186 & 980 & 2.47 & 695 & 6.46 \\
\hline $\mathrm{p}$ & 0.349 & 0.169 & 0.018 & 0.450 & 0.888 & 0.000 \\
\hline \multicolumn{7}{|l|}{ Celery } \\
\hline Organic & 2931 & 2502 & 10,500 & 1322 & 38,775 & 8613 \\
\hline $\mathrm{SD}$ & 109 & 128 & 350 & 65.0 & 2113 & 794 \\
\hline Conventional & 2531 & 1536 & 11,270 & 742 & 29,813 & 7276 \\
\hline $\mathrm{SD}$ & 51.9 & 41.7 & 700 & 28.8 & 377 & 116 \\
\hline $\mathrm{p}$ & 0.005 & 0.000 & 0.164 & 0.000 & 0.002 & 0.045 \\
\hline \multicolumn{7}{|l|}{ Carrot } \\
\hline Organic & 2135 & 1570 & 11,060 & 736 & 24,952 & 3101 \\
\hline $\mathrm{SD}$ & 147 & 127 & 210 & 28.6 & 669 & 142 \\
\hline Conventional & 2067 & 1255 & 8610 & 923 & 21,182 & 2287 \\
\hline SD & 0.000 & 31.7 & 0.000 & 68.3 & 467 & 0.000 \\
\hline $\mathrm{p}$ & 0.467 & 0.014 & 0.000 & 0.012 & 0.001 & 0.001 \\
\hline
\end{tabular}


Continued

\begin{tabular}{ccccccc}
\hline Potato & & & & & & \\
\hline Organic & 2118 & 1312 & 21,350 & 198 & 27,210 & 3592 \\
SD & 0.000 & 46.9 & 3920 & 5.85 & 100 & 219 \\
Conventional & 1374 & 1139 & 13,230 & 125 & 15,395 & 1861 \\
SD & 28.9 & 63.9 & 140 & 1.60 & 325 & 25.8 \\
p & 0.000 & 0.020 & 0.023 & 0.000 & 0.000 & 0.000 \\
Onion & & & & & & \\
\hline Organic & 1965 & 1253 & - & 264 & 20,300 & 3851 \\
SD & 184 & 74.7 & - & 42.8 & 1750 & 413 \\
Conventional & 1744 & 1010 & - & 194 & 16,947 & 2113 \\
SD & 29.2 & 47.3 & - & 11.9 & 513 & 19.3 \\
P & 0.110 & 0.009 & - & 0.053 & 0.033 & 0.002 \\
\hline
\end{tabular}

difference was significant in the case of the parsley root, celery and potato. The Ca concentration in organic vegetables varied from $1845 \mathrm{mg} \cdot \mathrm{kg}^{-1}$ in the beet to $3931 \mathrm{mg} \cdot \mathrm{kg}^{-1}$ in the celery. Amount of this element in conventional crops was $1374 \mathrm{mg} \cdot \mathrm{kg}^{-1}$ in the potato to $2531 \mathrm{mg} \cdot \mathrm{kg}^{-1}$ in the celery. The elemental analysis showed that organic vegetables had generally a higher level of $\mathrm{Mg}$ and the difference was statistically significant in the case of the beet, celery, carrot, potato, and onion.

Among organic crops, the highest level of $\mathrm{Mg}$ was recorded in parsley leaves $\left(2886 \mathrm{mg} \cdot \mathrm{kg}^{-1}\right)$, the lowest in onion $\left(1253 \mathrm{mg} \cdot \mathrm{kg}^{-1}\right)$. Similar results were found in the conventional crops where the highest concentration was recorded in the case of parsley leaves $\left(2568 \mathrm{mg} \cdot \mathrm{kg}^{-1}\right)$ and the lowest in onion $\left(1010 \mathrm{mg} \cdot \mathrm{kg}^{-1}\right)$. Similarly, as in the case of $\mathrm{Ca}$ and $\mathrm{Mg}$, the highest concentration of $\mathrm{N}$ was found in the parsley leaves, which was $36,680 \mathrm{mg} \cdot \mathrm{kg}^{-1}$ for the organic harvest and 25,270 $\mathrm{mg} \cdot \mathrm{kg}^{-1}$ for the conventional one. Again, the organic vegetables generally revealed a higher level of N. Statistically significant differences were found in beet, carrot, and potato. On the other hand, a significantly higher level of $\mathrm{N}$ was found in the conventional leek compared to the organic one. The $\mathrm{Na}$ content tended to be higher in organic crops. In 4 out of 8 vegetables, the concentration of this element was significantly higher and generally, it varied between $198 \mathrm{mg} \cdot \mathrm{kg}^{-1}$ in potato to $1322 \mathrm{mg} \cdot \mathrm{kg}^{-1}$ in celery. A particularly high content of $\mathrm{Na}$ was found in organic beet and celery where the level of this element was almost twice as high as in conventional beet and celery. Significant differences in the concentration of $\mathrm{K}$ between vegetables grown in organic and conventional ways were found in the case of the beet, celery, carrot, potato, and onion. Only the conventionally grown beet revealed a higher concentration compared to the organic one, in remaining vegetables a higher level was found in organic crops. In conventional crops, the level of $\mathrm{K}$ varied between $16,947 \mathrm{mg} \cdot \mathrm{kg}^{-1}$ in onion and $60,811 \mathrm{mg} \cdot \mathrm{kg}^{-1}$ in parsley leaves. Similarly, as in the conventional crops, the highest level of $\mathrm{K}$ was found in 
parsley leaves $\left(69,066 \mathrm{mg} \cdot \mathrm{kg}^{-1}\right)$; however, the lowest was in the case of the beet $\left(17,731 \mathrm{mg} \cdot \mathrm{kg}^{-1}\right)$.

Significant differences in the concentration of $\mathrm{P}$ were found between the crops from the organic and conventional farm. In the case of all vegetables except the beet, the level of this element was importantly higher in organically grown vegetables. An especially high level of this element was found in celery, in the organic one $\mathrm{P}$ concentration was $8631 \mathrm{mg} \cdot \mathrm{kg}^{-1}$ and in the conventional one $7276 \mathrm{mg} \cdot \mathrm{kg}^{-1}$. The lowest level of $\mathrm{P}$ among organic vegetables was recorded in beet (2087 $\left.\mathrm{mg} \cdot \mathrm{kg}^{-1}\right)$ and among conventional ones in potato $\left(1861 \mathrm{mg} \cdot \mathrm{kg}^{-1}\right)$.

The concentration of macro elements in the soil and $\mathrm{pH}$ values is presented in Table 2. The concentration of $\mathrm{Ca}$ in the organic soil $\left(2503 \mathrm{mg} \cdot \mathrm{kg}^{-1}\right)$ was almost two times higher than in the conventional one $\left(1295 \mathrm{mg} \cdot \mathrm{kg}^{-1}\right)$. Also, $\mathrm{N}$ and $\mathrm{P}$ contents were much higher in the organically treated soil compared to the conventional one. A slightly higher level was also recorded in the concentration of $\mathrm{K}$ in the organic soil. On the other hand, a higher level of $\mathrm{Mg}$ and $\mathrm{Na}$ was reported in the conventionally treated soil; however, the differences were not of meaningful importance.

\section{Discussion}

Our results demonstrate that organically grown vegetables generally contain a significantly higher level of macro elements compared to the ones grown in a conventional way. It is commonly known that fertilizers, whether the mineral or organic ones importantly affect the content of elements in the soil as well as in plant tissues. Other very important factors are the physicochemical characteristics of the soil and the climate conditions.

The content of $\mathrm{Ca}$ in the soil depends primarily on the type of bedrock from which it originated and on the degree of weathering processes. In Poland, the content of $\mathrm{Ca}$ in the top layers of the mineral soil ranges from 1000 to 34,300 $\mathrm{mg} \cdot \mathrm{kg}^{-1}[11]$. Our results revealed a much lower concentration of $\mathrm{Ca}$ in the soil cultivated in a conventional way (1295 $\left.\mathrm{mg} \cdot \mathrm{kg}^{-1}\right)$, compared to the organic one (2503 $\mathrm{mg} \cdot \mathrm{kg}^{-1}$ ). This might be due to the regular compost application. Stępień and Adamiak [12] in their 5-year field study investigated the influence of the different type of fertilizers on the chemical properties of the soil. Their results clearly demonstrated that long-term compost application increases the content of Ca compared to another type of fertilizers. Plants usually contain quite a high amount of Ca, on average $5000-30,000 \mathrm{mg} \cdot \mathrm{kg}^{-1}$. The main reason for the high content of this element in the plant tissues is the elevated concentration of $\mathrm{Ca}$ in the soil solution. However, the uptake of $\mathrm{Ca}$ by the plant is usually slower than the uptake of other elements [13]. The biological factors affecting the Ca intake are primarily the species and variety of the plant, root and rhizosphere structure, plant transpiration, mycorrhiza activity, and the effect of phytohormones [14]. In our study, a significantly higher concentration of $\mathrm{Ca}$ was found in organic celery, potato, and parsley root. This is in agreement with the results of the 
Table 2. Average concentration of macro elements (mg. $\mathrm{kg}^{-1}$ dry matter) and $\mathrm{pH}$ of the organically and conventionally cultivated soils.

\begin{tabular}{cccccccc}
\hline & $\mathrm{Ca}$ & $\mathrm{Mg}$ & $\mathrm{N}$ & $\mathrm{Na}$ & $\mathrm{K}$ & $\mathrm{P}$ & $\mathrm{pH}$ \\
\hline Organic & 2503 & 503 & 1794 & 15.9 & 312 & 491 & 7.05 \\
Conventional & 1295 & 668 & 962 & 16.4 & 290 & 251 & 6.75 \\
\hline
\end{tabular}

meta-analysis conducted by Williams [5]. In 21 out of 47 studies, it was found that a higher content of $\mathrm{Ca}$ was reported in the organically grown vegetables; in 20 , the amount was similar between the two growing systems; in 6 only, a higher content was recorded in conventional plants. Similarly, Warman and Havard [15] in their 3-year study found an increased amount of $\mathrm{Ca}$ in organic carrot compared to conventional one.

The average concentration of $\mathrm{Mg}$ in arable soils of Poland is $770 \mathrm{mg} \cdot \mathrm{kg}^{-1}$. However, this value is much higher in western Poland were both farms are located and it reaches up to $980 \mathrm{mg} \cdot \mathrm{kg}^{-1}$ [16]. Soils of both organic and conventional farms evaluated in this study revealed $\mathrm{Mg}$ concentrations below average, which is $503 \mathrm{mg} \cdot \mathrm{kg}^{-1}$ and $668 \mathrm{mg} \cdot \mathrm{kg}^{-1}$, respectively. Generally, the lighter the soil, the less Mg it contains. That could explain lower concentration of this element in the organic soil compared to the conventional one. The organic farm was located on sandy and sandy loam soils. On the other hand, the soil of the conventional farm was represented mainly by podsols made of clay loam. Therefore, the soil physicochemical characteristics might be one of the reasons. $\mathrm{Mg}$ is very mobile; therefore, the majority of this element is often moved to deeper parts of the soil profile, particularly in the case of light sandy soils [17]. Considering the importance of this element in the plant growth it can be suspected that a significant dose of fertilizers containing $\mathrm{Mg}$ was applied in the conventional farm which would contribute to higher levels of it. The concentration of $\mathrm{Mg}$ in plant tissues varies between 3000 and $10,000 \mathrm{mg} \cdot \mathrm{kg}^{-1}$ and it depends on the plant species, its age, organ and plant demand for Mg. Generally, higher concentrations of this element are observed in the aboveground parts of the plant compared to the roots [18]. It agrees with our results where the $\mathrm{Mg}$ concentration in parsley leaves was found to be higher than in the root and generally the highest among all analyzed plants. Although the concentration of $\mathrm{Mg}$ was higher in the conventionally cultivated soil, plant tissue analysis demonstrated a higher $\mathrm{Mg}$ content in all organically grown vegetables compared to conventional ones. It is consistent with several other studies where a superior concentration of $\mathrm{Mg}$ in organically grown vegetables was reported [5] [15] [19].

Stępień and Adamiak [12] reported that on average $\mathrm{N}$ concentration in the soils cultivated in different ways vary between 800 and $1000 \mathrm{mg} \cdot \mathrm{kg}^{-1}$. The same authors demonstrated that among different types of fertilizers, organic ones increased the content of $\mathrm{N}$ in the most significant way. In our study, the organically cultivated soil was characterized by an increased concentration of N (1794 $\mathrm{mg} \cdot \mathrm{kg}^{-1}$ ) and it was over two times higher than in conventionally treated soil 
$\left(840 \mathrm{mg} \cdot \mathrm{kg}^{-1}\right)$. We hypothesize that the main reason for high $\mathrm{N}$ content is the frequent application of compost and cow manure in the organically managed farm. Nitrogen is considered to be one of the most important nutrients for the plant growth and development, primarily because it is essential in protein synthesis and it builds nucleic acids. Plants generally have an increased demand for $\mathrm{N}$ at various stages of development, particularly during leaf development and flowering [20]; therefore, this element is frequently applied as a mineral fertilizer. In our study, vegetables cultivated in the conventional way were supplied with this nutrient several times during the growing season, mainly in the form of ammonium sulphate. Nevertheless, our results indicate that the concentration of this element is higher in organic crops which correspond with the higher concentration of $\mathrm{N}$ in the soil.

$\mathrm{Na}$ is considered to be of secondary importance in the soil and its uptake depends mainly on the plant species as well as the $\mathrm{K}$ level of the soil, rather than the concentration of $\mathrm{Na}$ extractable from the soil. Colla et al. [21] in a two-year study demonstrated that the soil Na content did not significantly differ among organic, conventional and low input farming systems. The same authors observed that the $\mathrm{Na}$ content in the crops changes over time and one year they recorded a significantly higher level of this element in conventionally grown tomatoes but the following year there were no differences among farming systems. The meta-analysis by Worthington [19] showed that organic crops on average have about $20 \%$ more $\mathrm{Na}$ than conventional ones. In our study, no important differences in the soil $\mathrm{Na}$ content between two growing systems were observed. However, the concentration of $\mathrm{Na}$ in organic vegetables was significantly higher in 4 out of 8 vegetables analysed.

The total content of $\mathrm{K}$ in soil ranges from 8000 to $25,000 \mathrm{mg} \cdot \mathrm{kg}^{-1}$ and it depends on the clay fraction and soil mineral content. The highest concentration of $\mathrm{K}$ is found in heavy soils, where the clay content represents more than $3 \%$. In loose sandy soils, $\mathrm{K}$ concentration usually does not exceed $0.4 \%$ [11]. The monitoring of the soils, plants, agricultural products and foodstuffs in 2000 [16] reported that the average concentration of available $\mathrm{K}$ in the soils of Poland was $184 \mathrm{mg} \cdot \mathrm{kg}^{-1}$. The average for the south-west region, where both farms are located is, however, much higher and represents $270 \mathrm{mg} \cdot \mathrm{kg}^{-1}$. Generally, it was reported that mineral fertilizers increase the content of $\mathrm{K}$ in the soil to a larger extent than organic ones. Though, it is not entirely true in our study, where the content of available $\mathrm{K}$ in the soil was slightly higher in the organic samples (312 $\mathrm{mg} \cdot \mathrm{kg}^{-1}$ ) compared to conventional ones $\left(290 \mathrm{mg} \cdot \mathrm{kg}^{-1}\right)$. A lower concentration of $\mathrm{K}$ in the conventionally treated soil might be the result of a slightly more acidic $\mathrm{pH}$ which might lead to the higher loss rate [11]. Plants absorb $\mathrm{K}$ ions from the soil solution and usually contain more of this element than other minerals such as $\mathrm{Ca}, \mathrm{Mg}$ or $\mathrm{P}$. The concentration of $\mathrm{K}$ in plant cells exceeds significantly the content of this element in the surrounding environment. This indicates that $\mathrm{K}$ is actively transported by plants, despite the concentration gradient [11]. Our results clearly confirm this process. The content of $\mathrm{K}$ in the plant tis- 
sues is up to 100 times higher than in the soil. Due to many factors, the content of $\mathrm{K}$ in the plant can vary from 1245 to $33,190 \mathrm{mg} \cdot \mathrm{kg}^{-1}$. It was observed that the roots contained less $\mathrm{K}$ than the aboveground parts of the plant [18], which can be clearly observed in the obtained results for the root and leaves of parsley. Analysis of $\mathrm{K}$ concentration revealed that organically grown vegetables in our study had generally higher content of this element compared to conventional ones. The difference was significant in the case of celery, carrot, potato and onion. It is in agreement with the results obtained by Worthington [19] which showed that organic crops contain on average $10 \%$ more of $\mathrm{K}$ than conventional ones. On the other hand, Warman and Havard [15] demonstrated that the superior level of $\mathrm{K}$ in organic crops is not conclusive. Some vegetables grown in a conventional way, such as carrot, had a higher content of $\mathrm{K}$ over organic ones, but in the case of cabbage, it was opposite.

The total content of $\mathrm{P}$ in the soil varies from 200 to $1500 \mathrm{mg} \cdot \mathrm{kg}^{-1}$ and a significant amount of this element comes from soil organic matter [11]. The soil monitoring program [16] revealed that the average concentration of this element in Poland is $274 \mathrm{mg} \cdot \mathrm{kg}^{-1}$ and that the average for the south west region is 352 $\mathrm{mg} \cdot \mathrm{kg}^{-1}$. Furthermore, Lemanowicz and Koper [22] reported that arable soils usually contain more of this element and in Poland; it is on average $478 \mathrm{mg} \cdot \mathrm{kg}^{-1}$. In our study, the P content of the soil was generally higher than in Poland and in this region. It was observed that the organically treated soil was twice richer in $\mathrm{P}$ compared to the conventional one. Lemanowicz and Koper [22], in their studies, showed that the use of organic fertilizers in the form of manure significantly increases the amount of available $\mathrm{P}$, while mineral fertilizers in the form of ammonium nitrate reduce its amount in the soil. A similar research was conducted by Stępień and Adamiak [12]. They showed that among the different types of fertilizations, organic ones such as compost contributed to the highest increase of soil P content. This may explain the results obtained in our study, where an elevated amount of this element was found in the organic soil probably due to the regular application of compost and cow manure.

$\mathrm{P}$ is taken up by plants from the soil solution as soluble orthophosphates (as $\mathrm{H}_{2} \mathrm{PO}_{4}$ and $\mathrm{HPO}_{4}^{2-}$ ions) at a soil pH between 6 and 7. Generally, the content of available $\mathrm{P}$ in the soil is higher and the greater the soil moisture is, the better this element is absorbed by a plant. The roots of the plants are able to extract phosphorus from a soil solution containing very low concentrations of this element. Moreover, phosphorus content in roots and xylem is usually 100 to 1000 times higher than its content in the soil solution [13]. This was also observed in our results where the amount of $\mathrm{P}$ in vegetables far exceeded its content in the soil. Moreover, our results revealed a significantly higher concentration of $\mathrm{P}$ in the vegetables cultivated in an organic way; this was also confirmed in the study by Williams [5]. Warman and Havard [15] also reported in their study a higher P content in organic vegetables. However, the differences between the two growing systems were not significant. Worthington [19], on the other hand, observes that organic vegetables contained an average of $13 \%$ more of this element than con- 
ventional crops. The same author, by analysing various articles, found that as many as 55 of them reported higher $P$ content in organic crops, 37 lower, and 10 did not show any difference.

\section{Conclusion}

Based on the results of our study, we can conclude that organically grown vegetables contain a higher content of macro elements. It is believed that the main reason for the increased level of $\mathrm{N}, \mathrm{P}$ and $\mathrm{K}$ in the organically grown crop is due to the regular application of compost and cow manure and a generally more balanced nutrient management. It is also observed that among all studied vegetables parsley leaves accumulate a much higher level of $\mathrm{Ca}, \mathrm{Mg}, \mathrm{N}$ and $\mathrm{K}$. On the other hand, celery root shows the highest concentration of $\mathrm{Na}$ and $\mathrm{P}$.

\section{Conflicts of Interest}

The authors declare no conflicts of interest regarding the publication of this paper.

\section{References}

[1] Barański, M., Średnicka-Tober, D., Volakakis, N., Seal, C., Sanderson, R., Stewart, G.B., Benbrook, C., Biavati, B., Markellou, E., Giotis, C., Gromadzka-Ostrowska. J., Rembiałkowska, E., Skwarło-Sońta, K., Tahvonen. R., Janovská, D., Niggli, U., Nicot, P., Leifert, C. and Gromadzka-Ostrowska, J. (2014) Higher Antioxidant and Lower Cadmium Concentrations and Lower Incidence of Pesticide Residues in Organically Grown Crops: A Systematic Literature Review and Meta-Analyses. British Journal of Nutrition, 112, 794-811. https://doi.org/10.1017/S0007114514001366

[2] Walorczyk, S., Drożdżyński, D., Kowalska, J., Remlein-Starosta, D., Ziółkowski, A., Przewoźniak, M. and Gnusowski, B. (2013) Pesticide Residues Determination in Polish Organic Crops in 2007-2010 Applying Gas Chromatography-Tandem Quadrupole Mass Spectrometry. Food Chemistry, 139, 482-487. https://doi.org/10.1016/j.foodchem.2013.01.013

[3] Gnusowski, B., Nowacka, A., Walorczyk, S., Łozowicka, B. and Szpyrka, E. (2012) Pesticide Residues in Organic Food of Plant Origin in Poland in 2010. Progress in Plant Protection, 52, 127-132.

[4] Ismal, A. and Fun, C.F. (2003) Determination of Vitamin c, $\beta$-Carotene and Riboflavin Contents in Five Green Vegetables Organically and Conventionally Grown. Malaysian Journal of Nutrition, 9, 31-39.

[5] Williams, C.M. (2002) Nutritional Quality of Organic Food: Shades of Grey or Shades of Green? Proceedings of the Nutrition Society, 61, 19-24. https://doi.org/10.1079/PNS2001126

[6] Hansen, H. (1981) Comparison of Chemical Composition and Taste of Biodynamically and Conventionally Grown Vegetables. Plant Food for Human Nutrition, 30, 203-211. https://doi.org/10.1007/BF01094025

[7] Sankar, V., Veeraragavathatham, D. and Kannan, M. (2009) Effect of Organic Farming Practices on Post-Harvest Storage Life and Organoleptic Quality of Yellow Onion (Allium cepa). Indian Journal of Agricultural Sciences, 79, 608-614.

[8] Tinker, P.B. (2001) Organic Farming-Nutrient Management and Productivity. The 
Intemational Fertilizer Society, Proceedings No. 471, York, UK, 1-24.

[9] Nowosielski, O. (1988) Principles of Fertilizer Recommendations in Horticulture (pol.). PWRiL, Warsaw.

[10] Horwitz, W. (1975) Official Methods of Analysis. Association of Official Analytical Chemists, Washington DC, Vol. 222.

[11] Nowotna-Mieczyńska, A. (1976) Physiology of Mineral Plant Nutrition (pol). PWRiL, Warsaw.

[12] Stępień, A. and Adamiak, J. (2007) Effect of Fertilization Methods in Crop Rotation on Chemical Characteristics of Soil. Acta Agrophysica, 10, 465-472.

[13] Mengel, K. and Kirkby, E.A. (1983) Principles of Plant Nutrition (pol.). PWRiL, Warsaw.

[14] Wójcik, P. (1998) Calcium Nutrition in Higher Plants. Botanical News, 42, 41-52.

[15] Warman, P.R. and Havard, K.A. (1997) Yield, Vitamin and Mineral Contents of Organically and Conventionally Grown Carrots and Cabbage. Agriculture, Ecosystems and Environment, 61, 155-162. https://doi.org/10.1016/S0167-8809(96)01110-3

[16] Michna, W. (2001) A Report on Monitoring the Quality of Soils, Plants, Agricultural Products and Foodstuffs in 2000. The Ministry of Agriculture and Rural Development. Council for Quality Monitoring of Soils, Plants, Agricultural and Food Products, Warsaw.

[17] Kabata-Pendias, A. and Pendias, H. (1993) Biogeochemistry of Trace Elements (pol). Polish Scientific Publishers PWN, Warsaw.

[18] Lityński, T. and Jurkowska, H. (1982) Soil Fertility and Plant Nutrition (pol). Polish Scientific Publishers PWN, Warsaw.

[19] Worthington, V. (2001) Nutritional Quality of Organic Versus Conventional Fruits, Vegetables and Grains. The Journal of Alternative and Complementary Medicine, 7, 161-173. https://doi.org/10.1089/107555301750164244

[20] Skowrońska, M. and Filipek, T. (2009) Accumulation of Nitrogen and Phosphorus by Maize as the Result of a Reduction in the Potassium Fertilization Rate. Proceedings of ECOpole, 3, 109-112.

[21] Colla, G., Mitchell, J.P., Poudel, D.D. and Temple, S.R. (2002) Changes of Tomato Yield and Fruit Elemental Composition in Conventional, Low Input, and Organic Systems. Journal of Sustainable Agriculture, 20, 53-67. https://doi.org/10.1300/J064v20n02_07

[22] Lemanowicz, J. and Koper, J. (2009) The Content of Selected Phosphorus Forms in Soil and Redcloverand the Activity of Soil Phosphates in Relation to Differentiated Mineral and Organic Fertilization. Water Environment Rural Areas, 9, 119-139. 